Proc. Estonian Acad. Sci. Geol., 1999, 48, 3, 158-169

\title{
PROPOSAL FOR THE LOWER BOUNDARY- STRATOTYPE OF THE KEILA REGIONAL STAGE (UPPER ORDOVICIAN)
}

\author{
Olle HINTS and Jaak NÕLVAK
}

Institute of Geology, Tallinn Technical University, Estonia pst. 7, 10143 Tallinn, Estonia; olle@gi.ee,nolvak@gi.ee

Received 26 April 1999, in revised form 10 May 1999

\begin{abstract}
According to the latest view on stratigraphy, chronostratigraphic units, stages inclusive, can be unambiguously defined only by their lower boundary-stratotypes. The Ordovician regional stages of Estonia are mostly distinguished based on their content rather than their boundaries, and in many cases lack appropriate lower boundary-stratotypes. In this study we propose the boundarystratotype for the Keila Regional Stage. The lower boundary of the Keila Stage has commonly been understood as the base of the Kinnekulle K-bentonite. The suggested stratotype section and point is defined as the base of the Kinnekulle K-bentonite in a subsurface tunnel at Pääsküla Hillock, south of Tallinn, North Estonia. This K-bentonite bed can be widely traced in Baltoscandia, and the approximately coeval Millbrig K-bentonite is widespread in North America. Several microfossils could also be used to distinguish the lower boundary of the Keila Stage within Baltoscandia.
\end{abstract}

Key words: stratigraphy, boundary-stratotype, Ordovician, Keila Stage, Kinnekulle K-bentonite, Baltoscandia, chitinozoans.

\section{INTRODUCTION}

Stratigraphy has a remarkably long study history in Estonia going back to the 1850s. The Ordovician stratigraphic scheme of Estonia has become one of the most detailed schemes in the world (see Webby, 1998, fig. 4). Many of the Ordovician chronostratigraphic units defined in Estonia serve as the standard for a large area in the East European Platform, including the East Baltic, NW Russia, the Ukraine, and Belarus; and in Scandinavia, including Sweden, Norway, and Denmark (e.g., Männil, 1966; Jaanusson, 1976; Resheniya..., 1987; Männil \& Meidla, 1994). 
In recent years steps have been taken towards elaborating the global chronostratigraphic scheme of the Ordovician. The boundaries for the tripartite series-level subdivision of the Ordovician System are recommended, and the first global stage, the Darriwillian, has been approved (Webby, 1998). Moreover, in several areas, a revision of the Ordovician regional stratigraphy has started (e.g., Fortey et al., 1995).

Most of the Estonian chronostratigraphic units are defined as intervals characterized by a particular composition. However, the background for dating, the chronostratigraphic scale, can be unambiguously constructed only by designation of the so-called boundary-stratotype sections and points (see Salvador, 1994). Thus, the Estonian chronostratigraphic units that lack appropriately designated lower boundary-stratotypes deserve redefinition. This would make the idea of chronostratigraphy more precise, helping to distinguish it from litho- and biostratigraphy and to make the chronostratigraphic scheme more stable. In many cases the knowledge of regional geology appears to be sufficient to revise Estonian chronostratigraphic units according to the theoretical basis provided in the International Stratigraphic Guide, that is, to choose appropriate stratotype sections and points, without affecting the currently existing practice. In the present paper we propose the lower boundary-stratotype for the Keila Regional Stage (Fig. 1). The suggested stratotype section and point is set at the base of the Kinnekulle K-bentonite bed in a subsurface tunnel at Pääsküla Hillock, south of Tallinn, North Estonia.

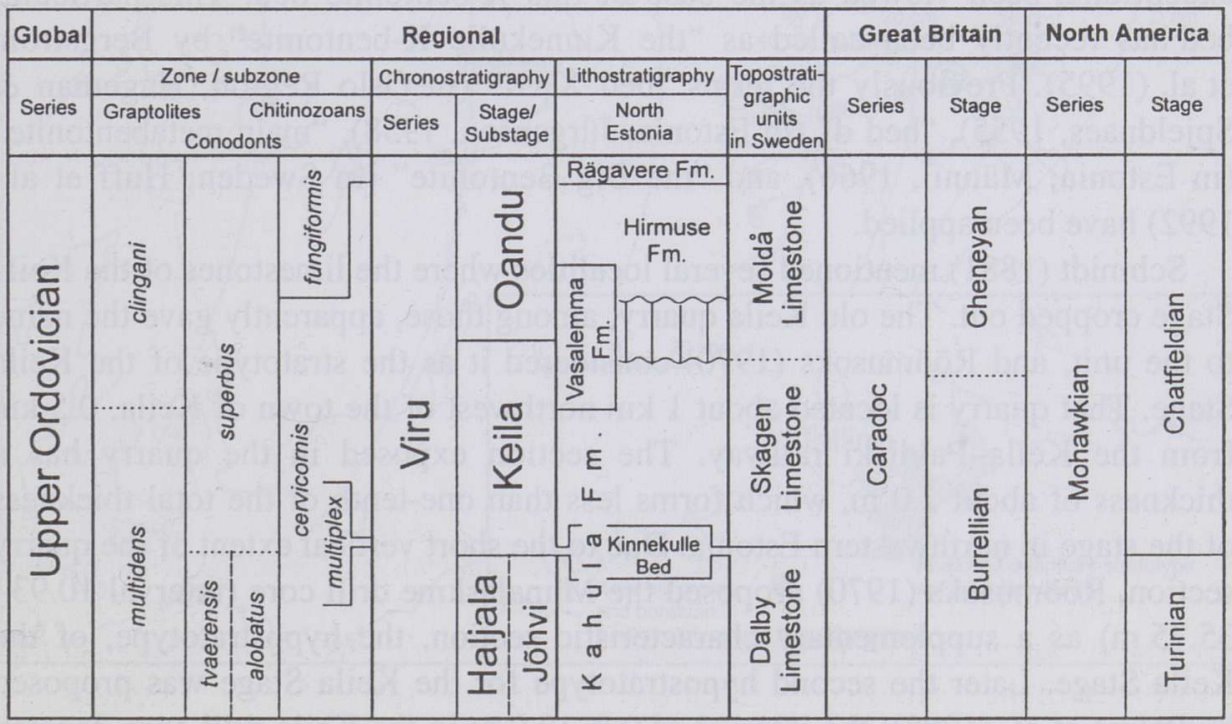

Fig. 1. Stratigraphic chart illustrating the position of the Keila Stage in relation to global and regional units (after Fortey at al., 1995; Nõlvak, 1997; Webby, 1998). 


\section{HISTORICAL BACKGROUND}

In the regional stratigraphical terminology, the geographical name Keila (Kegel) was first used by Schmidt (1881) to mark distinct "beds" (Schicht). Schmidt used different macrofossils [e.g., Horderleyella kegelensis (Alichova), Longvillia asmusi (Verneuil), Porambonites ventricosus Kutorga, Leiolichas illaenoides (Nieszkowski), Conolichas deflexus (Angelin), Atractopyge kutorgai (Schmidt)] to distinguish the Keila Beds from the underlying Jõhvi (Jewesche) and overlying Vasalemma (Wassalemsche) beds. The index $\mathrm{D}_{2}$ was employed to denote the Keila Beds. Afterwards Schmidt's Keila and Vasalemma beds were viewed together as an individual unit (Raymond, 1916; Bekker, 1923), until Öpik (1934) assigned the Vasalemma and Oandu beds into the Vasalemma (= Oandu) Stage (Stufe) separating the Keila Stage. Jaanusson (1945) contributed to the investigation of the Keila Stage, proposing its internal subdivision. Männil (1958) introduced the Ristna (lower) and Laagri (upper) substages, with the boundary between them at the level of a distinct faunal change coinciding with a thin K-bentonite layer. Subsequently different aspects of the Keila Stage have been studied by, e.g., Männil (1963, 1966), Rõõmusoks (1970), and Põlma et al. (1988).

Jaanusson \& Martna (1948) recognized the correlative value of K-bentonites (metabentonites) and bound the lower boundary of the Keila Stage to the thickest K-bentonite in Baltoscandia. Since Männil (1958), this boundary has, with few exceptions, been viewed as the base of this K-bentonite bed. This particular bed has recently been called as "the Kinnekulle K-bentonite" by Bergström et al. (1995). Previously the terms "bed XXII" (in Oslo Region; Hageman \& Spjeldnaes, 1955), "bed d" (in Estonia; Jürgenson, 1958), "main metabentonite" (in Estonia; Männil, 1966), and "the Big Bentonite" (in Sweden; Huff et al., 1992) have been applied.

Schmidt (1881) mentioned several localities where the limestones of the Keila Stage cropped out. The old Keila quarry, among those, apparently gave the name to the unit, and Rõõmusoks (1970) considered it as the stratotype of the Keila Stage. That quarry is located about $1 \mathrm{~km}$ northwest of the town of Keila, $0.5 \mathrm{~km}$ from the Keila-Paldiski railway. The section exposed in the quarry has a thickness of about $2.0 \mathrm{~m}$, which forms less than one-tenth of the total thickness of the stage in northwestern Estonia. Due to the short vertical extent of the quarry section, Rõõmusoks (1970) proposed the Munalaskme drill core (interval 10.93$35.75 \mathrm{~m})$ as a supplementary characteristic section, the hypostratotype, of the Keila Stage. Later the second hypostratotype for the Keila Stage was proposed by Põlma et al. (1988): the interval of $0.2-12.9 \mathrm{~m}$ in the Keila drill core, located some $50 \mathrm{~m}$ from the mentioned quarry. This drill core revealed that the Kinnekulle K-bentonite marking the boundary of the stage is about $10 \mathrm{~m}$ in subsurface. 


\section{THE TYPE LOCALITY}

The type locality for the lower boundary of the Keila Stage proposed herein is situated at Pääsküla Hillock, south of Tallinn, North Estonia (Fig. 2), where the composite section of limestones of the Kahula Formation is more than $10 \mathrm{~m}$ thick. The bedrock exposures at Pääsküla Hillock were known already to Schmidt (1858, 1881). In the late 1930s, V. Jaanusson and R. Männil investigated the locality. Rõõmusoks (1970) and Nõlvak (1996) published some of the descriptions of numerous individual sections provided by R. Männil. Hints et al. (1997) discussed some aspects of the Kinnekulle K-bentonite which crops out in the subsurface tunnels, extending horizontally for about $900 \mathrm{~m}$ in an eastwest and about $1100 \mathrm{~m}$ in a north-south direction.

The stratotype section and point proposed for the lower boundary of the Keila Stage is fixed at the base of the Kinnekulle K-bentonite in the subsurface tunnel near the entrance to shelter No. 4 (see fig. 1 in Hints et al., 1997). The approximate geographical coordinates of this section are $59^{\circ} 20^{\prime} 30^{\prime \prime} \mathrm{N}$ and $24^{\circ} 38^{\prime} 00^{\prime \prime}$ E. Although in some other geographical points the vertical extent

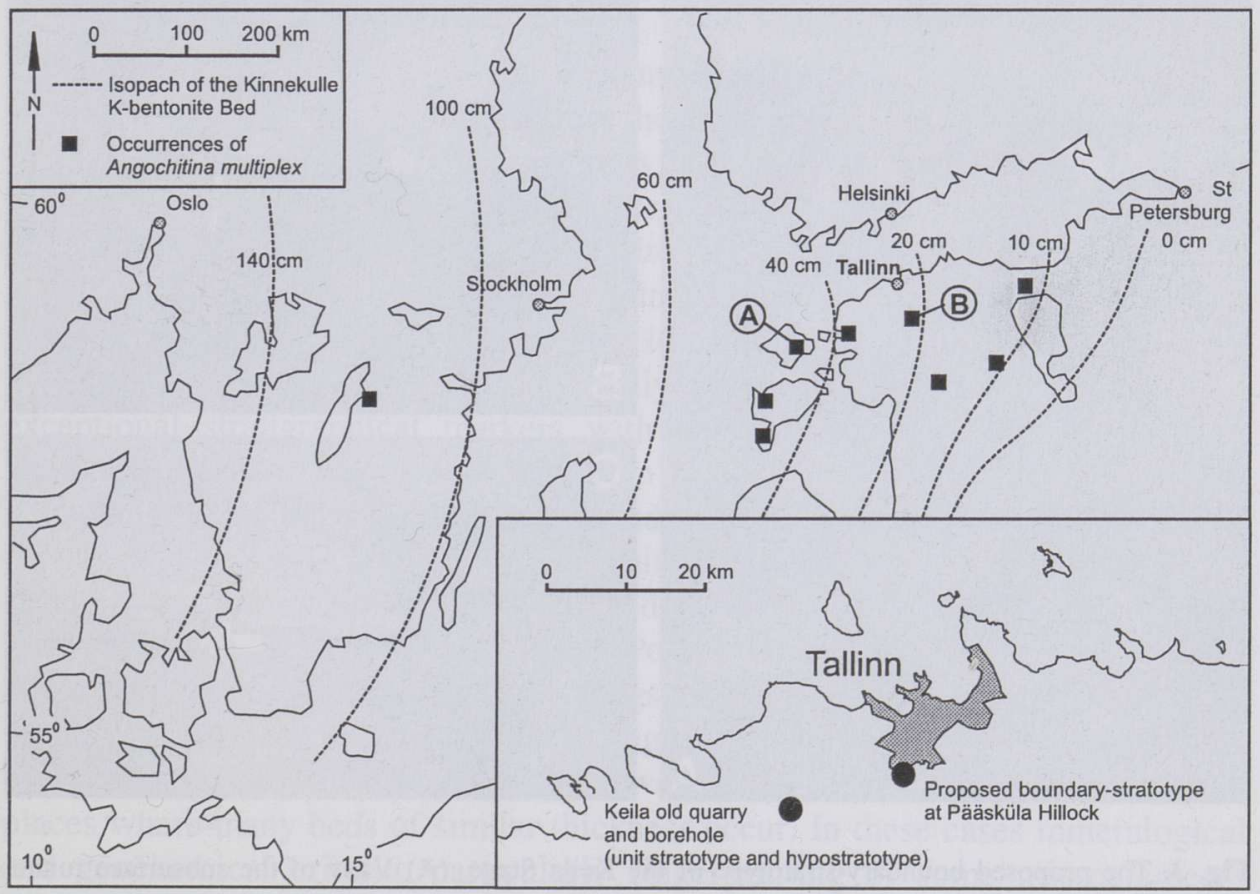

Fig. 2. Sketch map showing the distribution and thickness of the Kinnekulle K-bentonite (isopachs are given after Vingisaar, 1972; Bergström et al., 1995), the occurrences of Angochitina multiplex, and the approximate geographical positions of the proposed boundary-stratotype and the unit stratotype of the Keila Stage. A, Männamaa drill core (see Fig. 5); B, Rapla drill core (see Fig. 4). 
of the over- and underlying beds is larger than in this particular section, we favoured this one because of relatively easy accessibility.

In the type section, the approximately $30 \mathrm{~cm}$ thick K-bentonite bed contains prevalently illite-smectite and potassium feldspar. The main portion of the K-bentonite is lithologically plastic; at the base and at the top of the bed there are hard layers, approximately 0.5 and $7.0 \mathrm{~cm}$ thick and rich in feldspar (see Fig. 3; Hints et al., 1997). The base of the Kinnekulle Bed is very distinct, smooth, and slightly undulating, usually impregnated with pyrite. The upper limit of the bed is, in contrast, more or less transitional and uneven.

The results of the study of macrofossils at Pääsküla Hillock are summarized in Rõõmusoks (1970). The micropalaeontological study of the boundary interval is in progress; some results were published in Hints et al. (1997). Nevertheless, since the Kinnekulle Bed allows controlling the spatial extent of the boundary horizon, palaeontological data from other sections could well be used to characterize the lower boundary of the Keila Stage (see below).
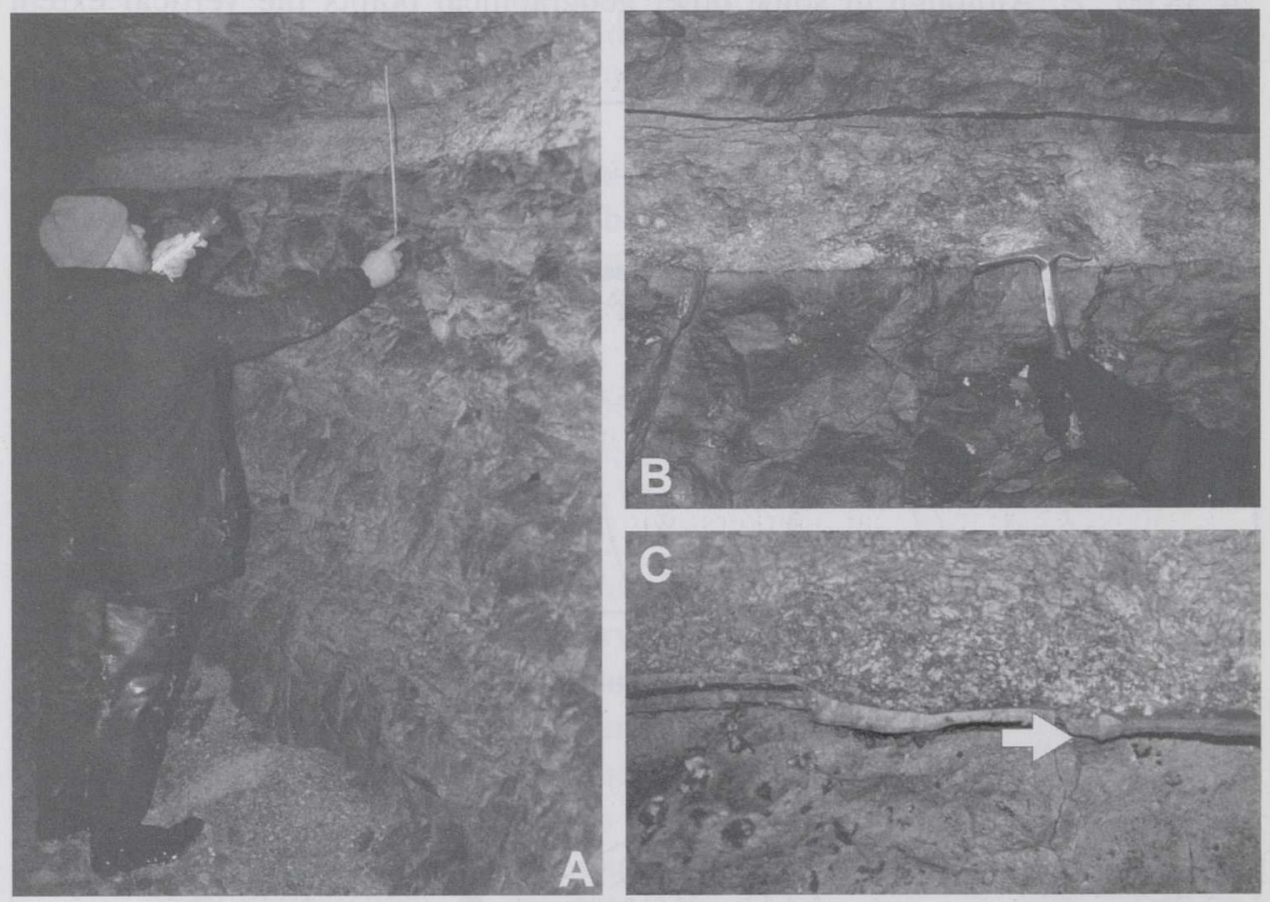

Fig. 3. The proposed boundary-stratotype of the Keila Stage. (A) View of the subsurface tunnel near the entrance to shelter No. 4 (see Hints et al., 1997, fig. 1), with the Kinnekulle Bed cropping out in the roof of the tunnel. (B) The Kinnekulle K-bentonite Bed. The hammer points to the base of the approximately $30 \mathrm{~cm}$ thick bed. (C) Detail of the basal portion of the Kinnekulle Bed. The arrow points to the boundary of the Keila Stage. The distinct layer above the arrow is the $\mathrm{K}$-feldspar-rich hard layer at the base of the K-bentonite bed. 
The main advantages of the above locality and the type section itself over other possible candidates for the lower boundary-stratotype of the Keila Stage can be summarized as follows.

1. In case of an outcrop, the material for study is not limited, as it would be in case of a drill core.

2. The Pääsküla Hillock locality is rich in various well-preserved macro- and microfossils (including brachiopods, trilobites, graptolites, chitinozoans, etc.), which are also rather extensively collected.

3. The locality provides the largest vertical and lateral exposure of the Jõhvi and Keila stages, being also the only permanent outcrop of the Kinnekulle $\mathrm{K}$-bentonite in this area.

4. The proposed type section is rather close (some $15 \mathrm{~km}$ ) to the denominative section and the hypostratotype of the Keila Stage.

5. The nature and extent of the outcrop provide good chances for its long-time preservation.

\section{BOUNDARY MARKERS}

\section{Lithological markers}

The lithology of the lower boundary interval of the Keila Stage is, except the occurrence of the K-bentonite, rather homogeneous. According to L. Põlma (unpublished data), the boundary falls within a sequence of argillaceous limestones with up to $25 \%$ skeletal debris in the stratotype area (the Kahula Formation; see Fig. 1). Dispersed kukersite kerogen occurs below and above the boundary; two distinct interlayers containing kukersite are recorded about 1.2 and $2.2 \mathrm{~m}$ below the boundary in the type locality.

K-bentonite layers represent virtually isochronous surfaces, constituting exceptional stratigraphical markers with a time resolution otherwise hardly attainable in the Palaeozoic (Bergström et al., 1995). Correspondingly, the Kinnekulle K-bentonite as the thickest and most widespread one in Baltoscandia (see Fig. 2) provides probably the best time marker one can desire in regional stratigraphy. It can be confidently traced over long distances in Scandinavia, Estonia, Latvia, parts of Denmark and Poland, and in the westernmost part of Leningrad District (Vingisaar, 1972; Bergström et al., 1995; Fig. 2 in this paper). Usually, the Kinnekulle Bed can be distinguished from the adjacent K-bentonites by its thickness and relative position. However, this may be complicated in some places where many beds of similar thickness occur. In these cases mineralogical and geochemical criteria, particularly fingerprinting of some microelements (Ti, Ga, Lu), may be of help (Bergström et al., 1995; Kiipli \& Kallaste, 1996).

Huff et al. (1992) suggested that the Kinnekulle K-bentonite has a counterpart in North America - the Millbrig K-bentonite. The idea that these beds represent one and the same volcanic eruption has been doubted on the basis of biotite phenocryst chemistry by Haynes et al. (1995). Nevertheless, the absolute age 
determinations (Kunk et al., 1988) and data on fossils indicate that the Kinnekulle and Millbrig beds are if not coeval, then at least of very similar age.

It has been reported that in some localities, particularly in Scandinavia, the Kinnekulle K-bentonite may consist of two adjacent beds separated by a thin layer of carbonate sediment (Thorslund, 1948). Whether in such cases the boundary of the Keila Stage should be correlated with the base of the lower or upper layer is unclear yet. A detailed geochemical study will possibly solve this question.

\section{Palaeontological markers}

It has been documented that volcanic ashfalls may have caused mass mortalities of benthic communities (e.g., Harper et al., 1995; Heikoop et al., 1997). It is also likely that the ash layer forming the Kinnekulle Bed had certain effect on biotas. However, studies on chitinozoans (Figs. 4 and 5 in this paper), jawed polychaetes (Hints, 1998), ostracodes (Jaanusson, 1976), and some other fossils (Huff et al., 1992) have revealed no extinction event. Correspondingly, the boundary of the Keila Stage coincides with a relatively minor biotic change, which reduces the chances of detecting the boundary in other localities. On the other hand, this implies that the boundary is defined within essentially continuous sedimentary record, which is one of the recommendations of the International Stratigraphic Guide (Salvador, 1994) for chronostratigraphic units.

To name some macrofossils that characterize the Keila Stage and appear in its lower part, Porambonites ventricosus Kutorga, Kiaeromena cryptoides (Oraspõld), Conolichas deflexus (Angelin), C. schmidti Dames, C. aequilobus (Stein.) may serve as examples. In addition, numerous species appear somewhat above the Kinnekulle Bed, approximately at the level of another K-bentonite bed ("bed e"; Männil, 1963).

Among microfossils, which provide higher biostratigraphical resolution and can be used also in case of limited drill core material, ostracodes, conodonts, and chitinozoans are of main importance. According to data by L. Sarv (see p. 61 and figs. 26, 27 in Põlma et al., 1988), in many localities the traditional lower boundary of the Keila Stage showed a distinct change in ostracode associations. The species typical of the Haljala Stage, like Tatrada memorabilis (Neckaja), Disulcina interminata Sarv, Pseudorakverella optata Sarv, disappear below (last specimens being occasionally found in the Kinnekulle Bed), and some new forms, like Leperditella prima Sarv, Tvaerenella longa (Sarv), Tallinnopsis grandis Sarv, and Tallinnopsis ovalis Sarv, appear above the Kinnekulle Bed.

The conodont zonation usually referred to as the biostratigraphical standard for Baltoscandia was elaborated on the basis of the Fjäcka section, Dalarna, Sweden, by Bergström (1971). In that section, the top of the Amorphognathus tvaerensis Zone and the base of the Amorphognathus superbus Zone are 


\section{Rapla drill core}
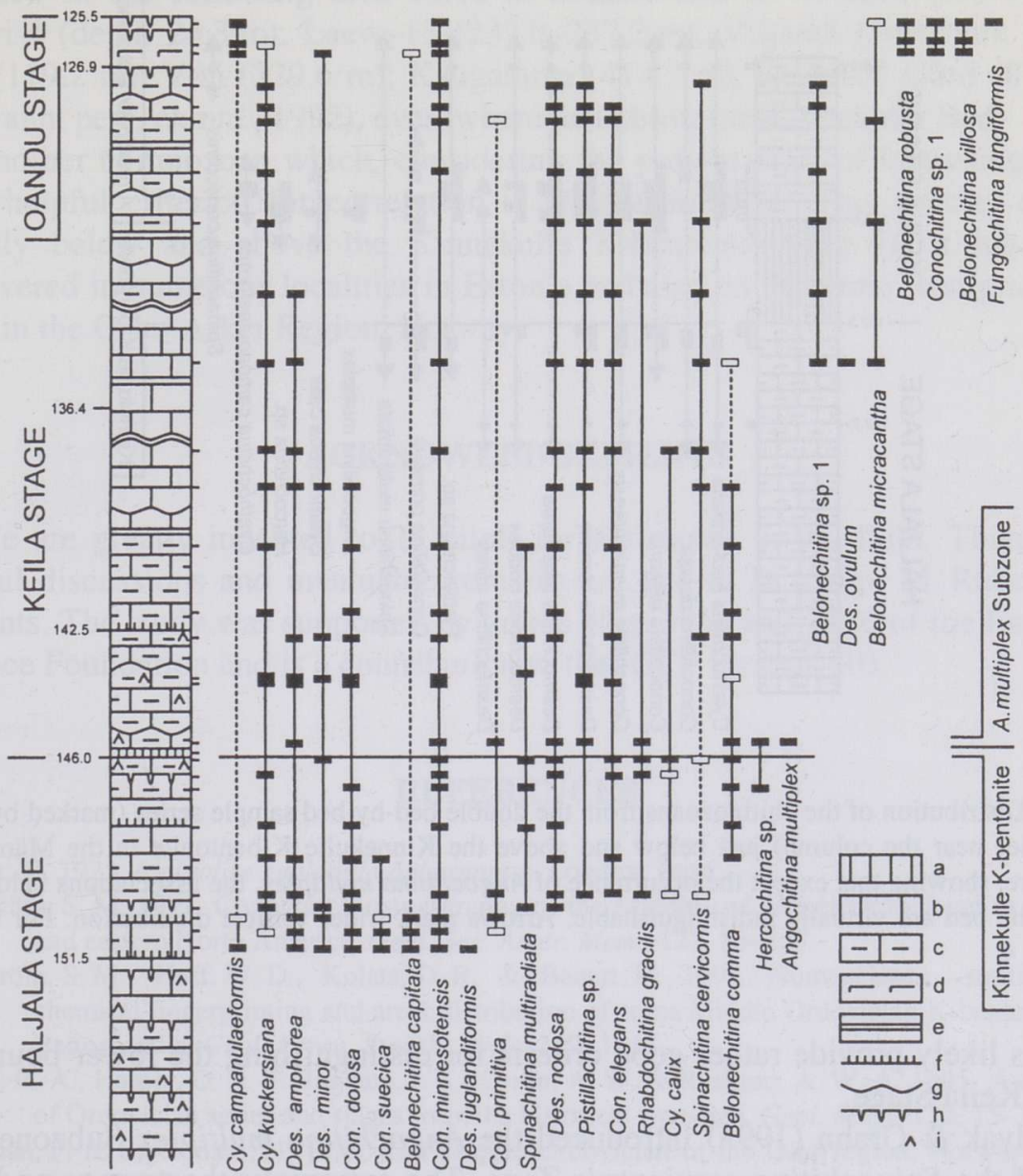

Fig. 4. Distribution of chitinozoans in the boundary beds of the Haljala and Keila stages in the Rapla drill core: Cy., Cyathochitina; Con., Conochitina; Des., Desmochitina; A., Angochitina. Open rectangles denote equivocal identification. Lithological legend: a, cryptocrystalline limestone; b, limestone; c, argillaceous limestone; d, marl; e, intercalations of marl; f, K-bentonite; g, nodular structure; h, discontinuity surface; i, dispersed kukersite kerogen.

tentatively fixed at the boundary between the Dalby and Skagen Limestones, that is, on the top of the Kinnekulle K-bentonite. However, considering the fact that the base of the A. superbus Zone is defined as the appearance of the first specimens of $A$. superbus (Rhodes), which evolved from A. tvaerensis Bergström, and that the section is partly tectonically jumbled (Jaanusson \& Martna, 1948), the actual boundary between the two zones may not exactly coincide with the Kinnekulle Bed. Despite the need for a more detailed study, these conodont 


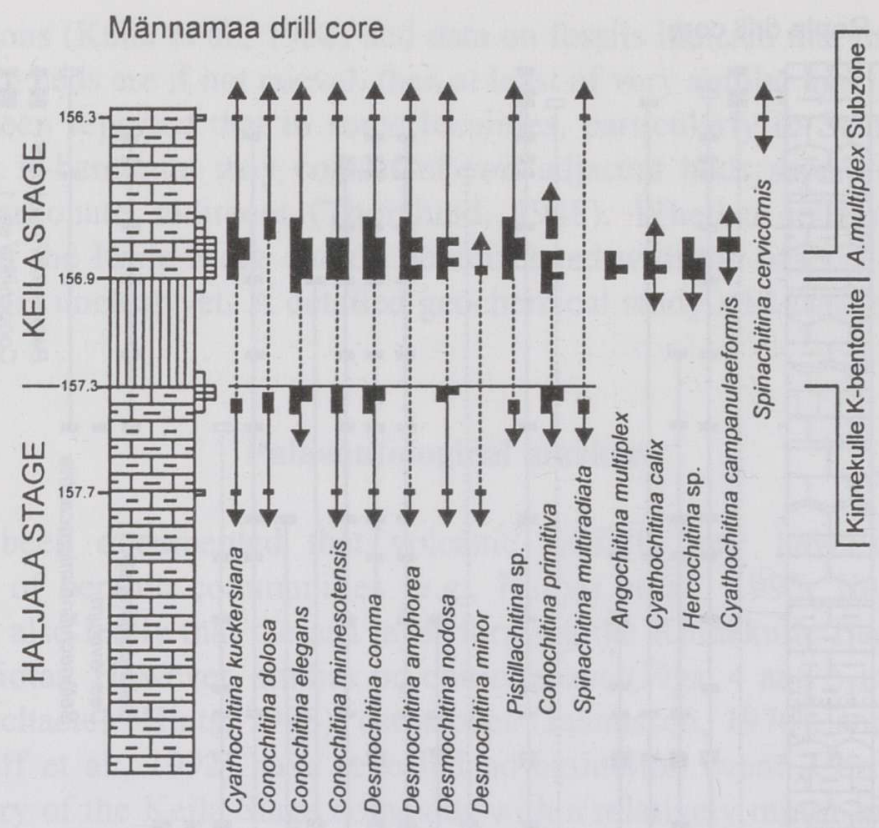

Fig. 5. Distribution of the chitinozoans from the double bed-by-bed sample series (marked by open rectangles near the column) just below and above the Kinnekulle K-bentonite in the Männamaa drill core, showing that except the occurrence of Angochitina multiplex, the associations below and above the bed are virtually indistinguishable. Arrows mark wider vertical distribution. For legend see Fig. 4.

species likely provide rather good criteria for distinguishing the lower boundary of the Keila Stage.

Nõlvak \& Grahn (1993) introduced the Angochitina multiplex Subzone as a part of the Spinachitina cervicornis Zone. The extremely short-range and rare A. multiplex (Schallreuter) occurs just above the Kinnekulle K-bentonite Bed. So far A. multiplex has not been recovered from the Pääsküla stratotype section. Except for this species, the assemblage of chitinozoans corresponds exactly to what has been recovered from above the Kinnekulle Bed in other sections. Since the boundary horizon can be traced with high precision on the basis of the Kinnekulle Bed, it is possible to demonstrate the distribution of A. multiplex in other sections (see Fig. 2). Figure 4 shows the general distribution pattern of chitinozoans in the upper part of the Haljala Stage and in the Keila Stage in the Rapla drill core, where the very short range of A. multiplex can be noted.

Figure 5 presents the results of the double bed-by-bed sampling of the Männamaa drill core, Hiiumaa Island, showing the very slight changes within chitinozoan assemblages below and above the Kinnekulle Bed, and the range and rare occurrence of A. multiplex. Two species recovered from the topmost part of the K-bentonite may derive from the fillings of burrows. In addition to the mentioned localities, the A. multiplex Subzone as a good marker has been 
revealed in the following drill cores in Estonia and in Sweden (see Fig. 2): Pagari-4 (depth $24.3 \mathrm{~m}$ ), Laeva-13 (237.0-237.2 m), Viljandi (349.0 m), Haapsalu (119.2 m), Viki (329.6 m), Kaugatuma (414.7 m), Smedsby Gård (87.6 m; Y. Grahn, pers. comm., 1992), everywhere just above the Kinnekulle Bed.

Another chitinozoan which, considering the present state of knowledge, can be a helpful criterion for correlation is Hercochitina sp. This species occurs slightly below and above the Kinnekulle K-bentonite (Fig. 4). It has been discovered in numerous localities in Estonia and also on the same stratigraphical level in the Oslo-Asker Region, Norway.

\section{ACKNOWLEDGEMENTS}

We are greatly indebted to T. Kiipli for assistance in the field. Thanks for fruitful discussions and invaluable remarks are due to D. Kaljo, M. Rubel, and L. Hints. The study was supported by grants Nos. 3751 and 3516 of the Estonian Science Foundation and is a contribution to the IGCP Project 410.

\section{REFERENCES}

Bekker, H. 1923. Ajaloolise geoloogia õpperaamat. Loodus, Tartu.

Bergström, S. M. 1971. Conodont biostratigraphy of the Middle and Upper Ordovician in Europe and eastern North America. Geol. Soc. Amer. Mem., 127, 83-157.

Bergström, S. M., Huff, W. D., Kolata, D. R. \& Bauert, H. 1995. Nomenclature, stratigraphy, chemical fingerprinting and areal distribution of some Middle Ordovician K-bentonites in Baltoscandia. Geol. Fören. Stockh. Förh., 117, 1-13.

Fortey, R. A., Harper, D. A. T., Ingham, J. K., Owen, A. W. \& Rushton, A. W. A. 1995. A revision of Ordovician series and stages from the historical type area. Geol. Mag., 132, 15-30.

Hageman, F. \& Spjeldnaes, N. 1955. The Middle Ordovician of the Oslo region, Norway. Norsk Geol. Tidsskr., 35, 29-51.

Harper, D. A. T., Scrutton, C. T. \& Williams, D. M. 1995. Mass mortalities on an Irish Silurian seafloor. J. Geol. Soc. London, 152, 917-922.

Haynes, J. T., Melson, W. G. \& Kunk, M. J. 1995. Composition of biotite phenocrysts in Ordovician tephras casts doubt on the proposed trans-Atlantic correlation of the Millbrig K-bentonite (United States) and the Kinnekulle K-bentonite (Sweden). Geology, 23, 9, 847-850.

Heikoop, J. M., Tsujita, C. J., Heikoop, C. E., Risk, M. J. \& Dicin, P. A. 1997. Effects of volcanic ashfall recorded in ancient marine benthic communities: comparison of a nearshore and an offshore environment. Lethaia, 29, 125-139.

Hints, O. 1998. Late Viruan (Ordovician) polychaete jaws from North Estonia and the St. Petersburg region. Acta Palaeontol. Polon., 43, 471-516.

Hints, O., Kallaste, T. \& Kiipli, T. 1997. Mineralogy and micropalaeontology of the Kinnekulle altered volcanic ash bed (Ordovician) at Pääsküla, North Estonia. Proc. Estonian Acad. Sci. Geol., 46, 3, 107-118.

Huff, W. D., Bergström, S. M. \& Kolata, D. R. 1992. Gigantic Ordovician volcanic ash fall in North America and Europe: biological, tectonomagmatic, and event-stratigraphic significance. Geology, 20, 875-878.

Jaanusson, V. 1945. Über die Stratigraphie der Viru - resp. Chasmops-Serie in Estland. Geol. Fören. Stockh. Förh., 67, 212-224. 
Jaanusson, V. 1976. Faunal dynamics in the Middle Ordovician (Viruan) of Baltoscandia. In The Ordovician System. Proc. Palaeont. Ass. Symposium, Birmingham, 1974 (Bassett, M. G., ed.), pp. 301-326. University of Wales Press, Cardiff.

Jaanusson, V. \& Martna, J. 1948. A section from the Upper Chasmops Series to the Lower Tretaspis Series at Fjäcka rivulet in the Siljan area, Dalarna. Bull. Geol. Inst. Univ. Uppsala, 32, 183-193.

Jürgenson, E. 1958. Metabentonites in Estonian SSR. Tr. Instituta geologii Akademii nauk Éstonskoj SSR, 2, 73-85 (in Russian).

Kiipli, E. \& Kallaste, T. 1996. Geochemical characterization of some Estonian metabentonites. Proc. Estonian Acad. Sci. Geol., 45, 2, 68-77.

Kunk, M. J., Samson, S. D. \& Roddick, J. C. $1988 .{ }^{40} \mathrm{Ar} /{ }^{39} \mathrm{Ar}$ age spectrum dating of biotite and sanidine and $\mathrm{U} / \mathrm{Pb}$ dating of zircon of mid-Ordovician bentonites from Sweden: a comparison with results from eastern North America. In Fifth International Symposium on the Ordovician System, Abstracts and Program, p. 49. St. John's, Newfoundland.

Männil, R. 1958. Grundzüge der Stratigraphie der Keila-Stufe (Ordovizium, Estland). ENSV TA Toim., 7, 235-246 (in Russian).

Männil, R. 1963. On the correlation of the Ordovician strata of Estonia and Leningrad region. $T r$. Instituta geologii Akademii nauk Éstonskoj SSR, 13, 3-40 (in Russian).

Männil, R. 1966. Evolution of the Baltic Basin during the Ordovician. Valgus, Tallinn (in Russian).

Männil, R. \& Meidla, T. 1994. The Ordovician System of East European Platform. IUGS Publication, 28.

Nõlvak, J. 1996. Pääsküla Hillock. In The Third Baltic Stratigraphical Conference. Abstracts. Field Guide (Meidla, T., Puura, I., Nemliher, J., Raukas, A. \& Saarse, L., eds.), pp. 98-100. Tartu University Press, Tartu.

Nõlvak, J. 1997. Ordovician. Introduction. In Geology and Mineral Resources of Estonia (Raukas, A. \& Teedumäe, A., eds.), pp. 52-55. Estonian Academy Publishers, Tallinn.

Nõlvak, J. \& Grahn, Y. 1993. Ordovician chitinozoan zones from Baltoscandia. Rev. Paleobot. Palynol., 79, 245-269.

Öpik, A. 1934. Über Klitamboniten. Acta Comment. Univ. Tartuensis, Ser. A, 26, 5.

Põlma, L., Sarv, L. \& Hints, L. 1988. Lithology and Fauna of the Caradoc Series Type Sections in North Estonia. Valgus, Tallinn (in Russian).

Raymond, P. E. 1916. The correlation of the Ordovician strata of the Baltic basin with those of North America. Bull. Mus. Comp. Zool. Harvard, 56, 3, 179-286.

Resheniya ... 1987. Resheniya Mezhvedomstvennogo soveshchaniya po ordoviku $i$ siluru Vostochno-Evropejskoj platformy 1984 g. so stratigraficheskimi skhemami. VSEGEI, Leningrad (in Russian).

Rõõmusoks, A. 1970. Stratigraphy of the Viruan Series (Middle Ordovician) in Northern Estonia. Valgus, Tallinn (in Russian).

Salvador, A. (ed.). 1994. International Stratigraphic Guide. A Guide to Stratigraphic Classification, Terminology, and Procedure. Second Edition. The Geological Society of America.

Schmidt, F. 1858. Untersuchungen über die Silurische Formation von Ehstland, Nord-Livland und Oesel. Arch. Naturk. Liv-, Ehst- und Kurl., ser. 2, 1.

Schmidt, F. 1881. Revision der ostbaltischen silurischen Trilobiten nebst geognostischer Übersicht des ostbaltischen Silurgebiets. Abt. I. Phacopiden, Cheiruriden und Encrinuriden. Mem. Acad. Sci. St. Petersb., ser. 7, 30.

Thorslund, P. 1948. The Chasmops Series of the Kullatorp core. In Deep Boring Through Ordovician and Silurian Strata at Kinnekulle, Västergötland (Waern, B., Thorslund, P. \& Henningsmoen, G., eds.). Bull. Geol. Inst. Univ. Uppsala, 32, 343-373.

Vingisaar, P. 1972. On the distribution of the main metabentonite stratum (d; XXII) in the Middle Ordovician of Baltoscandia. ENSV TA Toim. Keem. Geol., 21, 1, 62-70 (in Russian).

Webby, B. D. 1998. Steps toward a global standard for Ordovician stratigraphy. Newsl. Stratigr., 36, 1-33. 


\title{
KEILA LADEME ALUMISE PIIRI STRATOTÜÜP (ETTEPANEK)
}

\author{
Olle HINTS ja Jaak NÕLVAK
}

Arvestades nüüdisaegse kronostratigraafia nõudeid saab vastavaid üksusi, sealhulgas lademeid, ühemõtteliselt defineerida vaid piiripunktide fikseerimisega piiristratotüüpides. Kuna Eesti ordoviitsiumi lademed tuginevad eeskätt oma sisul, mitte aga üheselt määratletud piiridel, ei taga senine käsitus dateerimiseks vajaliku skaala ühemõttelisust. Siinses töös teeme ettepaneku pidada Keila lademe piiristratotüübiks paljandit Pääsküla kõvikul, kus lademe piiripunkt on fikseeritud Kinnekulle K-bentoniidi alumisele pinnale. Piiri selline definitsioon on vastavuses Keila lademe varasema käsitusega, seetõttu ei muutu lademe maht ega siiani edukalt rakendatud piirikriteeriumid. Kinnekulle kiht on Baltoskandias jälgitav laial alal, lisaks korreleeritakse seda Põhja-Ameerikas levinud Millbrigi K-bentoniidiga. Baltoskandias võimaldavad Keila ladet piiritleda ka mitmed mikrofossiilid.

\section{СТРАТОТИП НИЖНЕЙ ГРАНИЦЫ КЕЙЛАСКОГО ГОРИЗОНТА (ПРЕДЛОЖЕНИЕ)}

\section{Оллэ ХИНТС и Яак НЫЛВАК}

В соответствии с требованиями современной хроностратиграфии, выделение тех или иных подразделений, в том числе и горизонтов, однозначно определяется стратотипом их нижней границы. Однако критерием выделения ордовикских горизонтов Эстонии служат прежде всего фаунистические и литологические признаки и во многих случаях их границы не представлены в типовых разрезах. Поэтому в статье выдвинуто предложение рассматривать в качестве стратотипа нижней границы кейлаского горизонта подошву прослоя К-бентонита (прослоя Чиннекулле) в обнажении на пластовой возвышенности Пяэскюла (южная граница Таллинна, Северная Эстония). Такое определение границы согласуется с прежним ее пониманием и не меняет объем горизонта. Прослой K-бентонита Чиннекулле имеет широкое площадное распространение в Балтоскандии и хорошо коррелируется с таким же прослоем Миллбриг в Северной Америке. Тем самым уровень нижней границы кейлаского горизонта будет одним из наиболее достоверно прослеживаемых, причем как по прослою К-бентонита, так и по изменению состава разных групп микрофоссилий. 